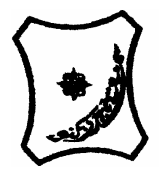

Bayero Journal of Pure and Applied Sciences, 6(2): 127 - 131

Received: July 2013

Accepted: December 2013

ISSN $2006-6996$

\title{
SYNTHESIS, CHARACTERIZATION OF BIOLOGICALLY ACTIVE N, N' - BIS(4-BENZENEAZOSALICYLIDENE)-O-PHENYLENEDIIMINATOCOBALT(II) COMPLEX
}

\author{
Aliyu, H. N. and Zayyan, R. S. \\ Department of Chemistry, Bayero University, P. M. B. 3011, Kano, Nigeria \\ E-mail: hnuhu2000@yahoo.com
}

\begin{abstract}
A Schiff base was prepared as reported, its cobalt(II) complex was synthesized by refluxing ethanolic mixture of the prepared schiff base and cobalt(II) chloride. The cobalt(II) Schiff base complex synthesized is brown, of percentage yield $65 \%$ and has decomposition temperature of $258^{\circ}$. The Schiff base and $N, N^{\prime}$ - bis(4-benzeneazo salicylidene)-o-phenylenediiminatocobalt(II) complex were characterized by solubility, melting point/decomposition temperature, molar conductivity, elemental analysis, IR spectra, bioassay and potentiomentry. The Schiff base and its cobalt(II) complex are slightly soluble in methanol and ethanol but are readily soluble in DMSO and DMF. The molar conductance measurement of the complex determined is $4.60 \mathrm{hm}^{-1} \mathrm{~cm}^{2} \mathrm{~mol}^{1}$, revealing its non electrolytic nature. The infrared spectral data of the ligand showed a band at1590 $\mathrm{cm}^{-1}$, which is attributed to $v(C=N)$ stretching frequencies. The same band is observed in the synthesized cobalt(II) Schiff base complex, suggesting that the Schiff base is coordinated to the cobalt(II) Schiff base complex. The bands in the regions $585 \mathrm{~cm}^{-1}$ and $511 \mathrm{~cm}^{-1}$ in the complex are assigned to $v(\mathrm{Co}-\mathrm{N})$ and $v(\mathrm{Co}-\mathrm{O})$ stretching vibrations confirming the coordination of the Schiff base to the manganese(II) ion. The elemental analysis result of the complex is consistent with 1:1 metal to Schiff base ratio. The dissociation constant of the determined is 11.67, indicating a week acid. The average number of Schiff base coordinated to cobalt ion is one, the stability constant and Gibbs free energy of the complex compound are $3.1 \times 1011$ and $-64.15 \mathrm{KJmol}-1$, respectively, suggesting that the complex is very stable. The antifungal and antibacterial tests carried out on the Schiff base and its iron(II) complex showed good activity.
\end{abstract}

Keywords: 4 -(Benzeneazo) Salicylaldehyde, Potentiometry, complex compound, schiff base, molar conductance and solubility.

\section{INTRODUCTION}

A Schiff base is a ligand, it contains of carbon nitrogen double bond $(-\mathrm{C}=\mathrm{N}-)$, in which the nitrogen atom is connected to an aryl or alkyl group but not hydrogen. The carbonyl group of the aldehyde gives aldimines while that of ketone gives ketoimines. Schiff base transition metal complexes have been known, for example, Ettling (1840) isolated a dark green crystalline product from the reaction of cupric acetate, salicyladehyde and aqueous ammonia (Holm et al., 1966). Ben Saber et al., (2005), reported the synthesis of a Schiff base derived from salicylaldeyde, and histidine and its complex compounds with divalent transition metal ions. The complexes were investigated by elemental analysis and were found to be of 1:1 metal to ligand ratio.In recent years, there has been enhanced interest in the synthesis and characterization of transition metal complexes containing Schiff base ligands due to their importance as catalyst in many reactions (Singh et al., 2006).

Chohan et al. (2006) reported the synthesis, antibacterial and antifungal activities of schiff bases derived from acetylacetone and amino acids and their cobalt(II), copper(II), nickel(II), and zinc(II) complexes. The schiff bases and their complexes are intensively colored, air and moisture stable amorphous solids. They decompose without melting, are insoluble in common organic solvents and only soluble in water, DMF, and DMSO. The molar conductance values of the soluble complexes in $\operatorname{DMF}\left(10^{-3} \mathrm{M}\right.$ solution at $\left.25^{\circ} \mathrm{C}\right)$ are very low and fall in the range, $26-35 \mathrm{ohm}^{-1} \mathrm{~cm}^{2} \mathrm{~mol}^{-1}$ ) indicating that they are all non-electrolytes. The complexes having molar ratios of metal: ligand as 1:1 showed higher values $\left(122-128 \mathrm{ohm}^{-1} \mathrm{~cm}^{-2} \mathrm{~mol}^{-1}\right)$ an indication that they are electrolytes. The elemental analysis data agreed well with the proposed formulae for the ligands and also confirmed the $\left[\mathrm{M}(\mathrm{L})_{2}(\mathrm{OH})_{2}\right]$ and $\left[\mathrm{M}(\mathrm{L})\left(\mathrm{OH}_{2}\right)_{4}\right] \mathrm{Cl}$ compositions of the metal(II) chelates. The synthesized amino acid-derived compounds showed antibacterial and antifungal properties. In comparison, the cobalt(II), copper(II), Nickel(II) and zinc(II) metal complexes of these compounds showed more activity against one or more bacterial and fungal stains.

Gavali and Henkarep, 2007 reported the preparation of $\mathrm{Co}(\mathrm{II}), \mathrm{Ni}(\mathrm{II}) \mathrm{Cu}(\mathrm{II}), \mathrm{Zn}(\mathrm{II})$ and $\mathrm{Cd}(\mathrm{II})$ complexes of tridentate ligand derived from 5-(2'thiazolylazo) salicylaldehyde and $\mathrm{p}$ - chloroaniline and characterization by various physico-chemical methods. The ligand was prepared by refluxing equimolar concentration of $5\left(2^{\prime}-\right.$ thiazolylazo) salicylaldehyde $(0.2334 \mathrm{~g}, 1 \mathrm{~mole})$ in $50 \mathrm{~cm}^{3}$ ethanol with p-chloroaniline $(0.1412 \mathrm{~g}, 1 \mathrm{~mole})$ in $15 \mathrm{~cm}^{3}$ ethanol for 4hours. . The result of the characterization revealed that the complexes were brightly coloured and thermally stable at least up to $200^{\circ} \mathrm{C}$. They are soluble in water and common organic solvent but show maximum solubility in DMF and DMSO at room temperature. 
They show very low molar conductance of about 20 $\mathrm{ohm}^{-1} \mathrm{~cm}^{2} \mathrm{~mol}^{-1}$ indicates their non-electrolytic nature. The analytical data of the complexes indicated $1: 1$ metal : Schiff base stoichiometry. The IR spectra of the ligand shows a medium broad band centered at $3000 \mathrm{~cm}^{-1}$ due to intra-molecular hydrogen bond $\mathrm{rO}$ $\mathrm{H})$. In the spectra of metal complexes the broad band disappears indicating deprotonation and involvement of the phenolic oxygen in bonding with metal ions. The strong band at $1625 \mathrm{~cm}^{-1}$ is assigned to the $\checkmark(C=N)$ stretching vibration observed in the ligand and this band undergoes a negative shift $\left(-10 \mathrm{~cm}^{-1}\right)$ in the complexes indicating the participation of the azomethine nitrogen in coordination. The spectral region at $1600-1400 \mathrm{~cm}^{-1}$ is complicated because of the stretching modes of $\quad(\mathrm{C}=\mathrm{C})$ and $(\mathrm{N}-\mathrm{N})$ which are superimposed in the same region. The bands observed in region $470 \mathrm{~cm}^{-1}$ and $320 \mathrm{~cm}^{-1}$ can be attributed to $\mathrm{M}-\mathrm{O}$ and $\mathrm{M}-\mathrm{N}$ atom. The ligand and its metal complexes were screened against Escherichia coli, Bacillus subtillis, Klebsiella pneumonia, pseudornonas aerogens, salmonella paratyphi $B$, staphylococcus aurens and proteus vulgaris by disc diffusion technique. The test solutions were prepared in DMF and DMSO at different concentrations. Nutrient agar was used as culture medium. The zones of inhibition formed were measured in milimeter. $\mathrm{Cu}$ (II) complex was found to be highly active against staphylococcus aureus and Cd(II) complex exhibited moderate activity against Bacillus subtillis. The $\mathrm{Co}$ (II) and $\mathrm{Cd}$ (II) complexes were found to be highly active inhibitor for Rhizopus fungus. This paper reports synthesis, characterization of biologically active $\mathrm{N}, \mathrm{N}^{\prime}$ bis(4-benzeneazo phenylenediiminatocobalt(II) complex

\section{MATERIALS AND METHODS}

All the glass-wares used were washed with detergent, rinsed with distilled water and dried in an oven. All the reagents and solvents used were of analytical grade(AnalaR or $\mathrm{BDH})$ and were used without further purification. Molar conductance measurements were carried out using Cyber Scan 500 model. Electric metler balance model $A B 54$ was used for weighing. Infrared spectral analysis data were recorded using Fourier Transform IR Genesis series model Nujol, within $400-4000 \mathrm{~cm}^{-1}$. The $\mathrm{pH}$ measurements were carried out using Jenway $\mathrm{pH}$ meter model 3320. The melting/decomposition temperatures were carried out using Gallenkamp melting point apparatus.

\section{Preparation of the Schiff base ligand}

A $0.01 \mathrm{~mol}(1.814 \mathrm{~g})$ of o-phenylenediamine was added slowly into a solution of $0.02 \mathrm{~mol}(4.5245 \mathrm{~g})$ (Benzeneazo) salicylaldehyde(an intermediate) in $20 \mathrm{~cm}^{3}$ ethanol. After refluxing the reaction mixture for 2 hours, the precipitate that formed was separated, washed several times using ethanol, followed by recrystallisation in ethanol and drying at $50^{\circ} \mathrm{C}$ in an oven overnight(Jianning et al., 2005).

\section{Preparation of cobalt(II) Schiff base complex}

The complex was prepared by refluxing a mixture of aqueous solution of $\mathrm{CoCl}_{2} \cdot 6 \mathrm{H}_{2} \mathrm{O}(1.0 \mathrm{mmol} ; 0.238 \mathrm{~g})$ and hot ethanolic solution of the prepared Schiff base $(0.524 \mathrm{~g})$ for 2 hours. The reaction mixture was allowed to cool in an ice bath and the greenish yellow precipitate obtained was separated, washed with ethanol and diethyl ether, followed by drying at $50^{\circ} \mathrm{C}$ overnight(Jianning et al., 2005).

\section{Determination of dissociation constant(pKa) of the Schiff base}

The dissociation constant of the Schiff base ligand was determined by introducing a standardized $\mathrm{pH}$ meter electrode into a $400 \mathrm{~cm}^{3}$ beaker containing magnetic stirrer bar, $90 \mathrm{~cm}^{3}$ water, $100 \mathrm{~cm}^{3}$ of $0.2 \mathrm{~mol} \mathrm{\textrm {dm } ^ { - 3 }}$ $\mathrm{KNO}_{3}$ and $10 \mathrm{~cm}^{3}$ of $0.4 \mathrm{~mol} \mathrm{dm} \mathrm{m}^{-3}$ Schiff base ligand solution. To this mixture, $10 \mathrm{~cm}^{3}$ of standardized $0.5 \mathrm{~mol} \mathrm{dm}^{-3}$ aqueous solution of $\mathrm{NaOH}$ was added gradually and the corresponding $\mathrm{pH}$ value recorded after each addition(Gregory et al., 1978).

\section{Determination of number of coordinated Schiff base in the complex}

To a $400 \mathrm{~cm}^{3}$ beaker containing $100 \mathrm{~cm}^{3}$ of $0.2 \mathrm{~mol} \mathrm{dm}^{-}$ $3 \mathrm{KNO}_{3}, 10 \mathrm{~cm}^{3}$ of $0.1 \mathrm{~mol} \mathrm{\textrm {dm } ^ { - 3 }} \mathrm{HNO}_{3} 90 \mathrm{~cm}^{3}$ of water and $1 \mathrm{mmole}$ of cobalt(II) chloride were added. Now $10 \mathrm{~cm}^{3}$ of $0.4 \mathrm{~mol} \mathrm{dm}^{-3}$ sodium salt of the Schiff base ligand which was prepared by neutralizing a weighed solid ligand with calculated amount of standardized $0.5 \mathrm{~mol} \mathrm{dm}^{-3} \mathrm{NaOH}$ solution. After each $0.2 \mathrm{~cm}^{3}$ aliquote addition the corresponding $\mathrm{pH}$ was recorded. From the knowledge of the $\mathrm{pH}$ recorded, the average number of coordinated Schiff base permanganese(II) ion was calculated as reported by Robert and Angelici( 1977).

\section{RESULTS AND DISCUSSION}

The ligand, N, N' - bis(4-benzeneazo salicylidene)-ophenylenediime was prepared and recrystallized as reported by Jianning et $a(2006)$. It has an orange colour, a melting point of $193^{\circ} \mathrm{C}$ and percentage yield of $70 \%$. The reaction of prepared ligand and cobalt(II) chloride gave $\mathrm{N}, \mathrm{N}^{\prime}$ - bis(4-benzeneazo salicylidene)-ophenylenediiminatocobalt(II) complex. The complex is brown in colour, has decomposition temperature of $257^{\circ} \mathrm{C}$ and percentage yield of $65 \%$ (Table 1 ). The solubility tests of the ligand and its cobalt(II) complex in water and common organic solvents carried out showed that both the ligand and the cobalt(II) complex are insoluble in water, slightly soluble in most organic solvents but readily soluble in dimethyl sulphoxide(DMSO) and dimethyl formamide(DMF). The result can be seen in Table 2 .

The molar conductance measurements (Table 3 ) on the complex determined in $10^{-3} \mathrm{M}$ DMSO solution is 4.6 ohm ${ }^{-1} \mathrm{~cm}^{2} \mathrm{~mol}^{-1}$, which is low, suggesting that the complex is non electrolyte(Geary, 1971). The infrared spectral band of the Schiff base ligand at $1590 \mathrm{~cm}^{-1}$ is assigned to $\forall(C=N)$ stretching vibration. The same spectral band was observed in the complex but in the lower frequency, $1530 \mathrm{~cm}^{-1}$, suggests the coordination of the Schiff base to cobalt(II) ion.

The bands at $585 \mathrm{~cm}^{-1}$ and $511 \mathrm{~cm}^{-1}$ are attributable to $(\mathrm{M}-\mathrm{N})$ and $(\mathrm{M}-\mathrm{O})$ stretching vibrations, respectively, confirming the coordination of the ligand to the cobalt ion(Ahmed and Akhtar, 1983; Abdulsamath et al., 1992). 
The result is presented in Table 4. The antibacterial test carried out on the ligand showed only minimal activity on $E$. coli $s p p$ with a diameter of inhibition zone of $13 \mathrm{~mm}$ per $3000 \mu \mathrm{g}$ concentration. The cobalt(II) complex on the other hand showed higher activity against the bacterial isolates particularly at $3000 \mu \mathrm{g}$ concentration with a diameter of inhibition zone of $25 \mathrm{~mm}$ (Table 5). The results of the antifungal activities of the ligand and its cobalt(II) complex also showed that the metal complex exhibits higher activity against the fungal isolate than the ligand. The result also showed that the activity is higher in $3000 \mu \mathrm{g}$ concentration and the complex is more active against
C. Albican spp as indicated by larger diameter of inhibition(Table 6). The dissociation constant of the ligand determined is 11.67 , which revealed that it is highly basic(Table 7). The ratio of cobalt(II) ion ligand determined potentiometrically is $1: 1$ (Table 8 ). The stability constant and the Gibb's energy of cobalt(II) complex are $3.16 \times 1011$ and $-64.15 \mathrm{KJmol}^{-}$ ${ }^{1}$ (Table 9).

On the basis of the spectral data, other analytical results and literature, the following molecular structure of the complex is proposed.

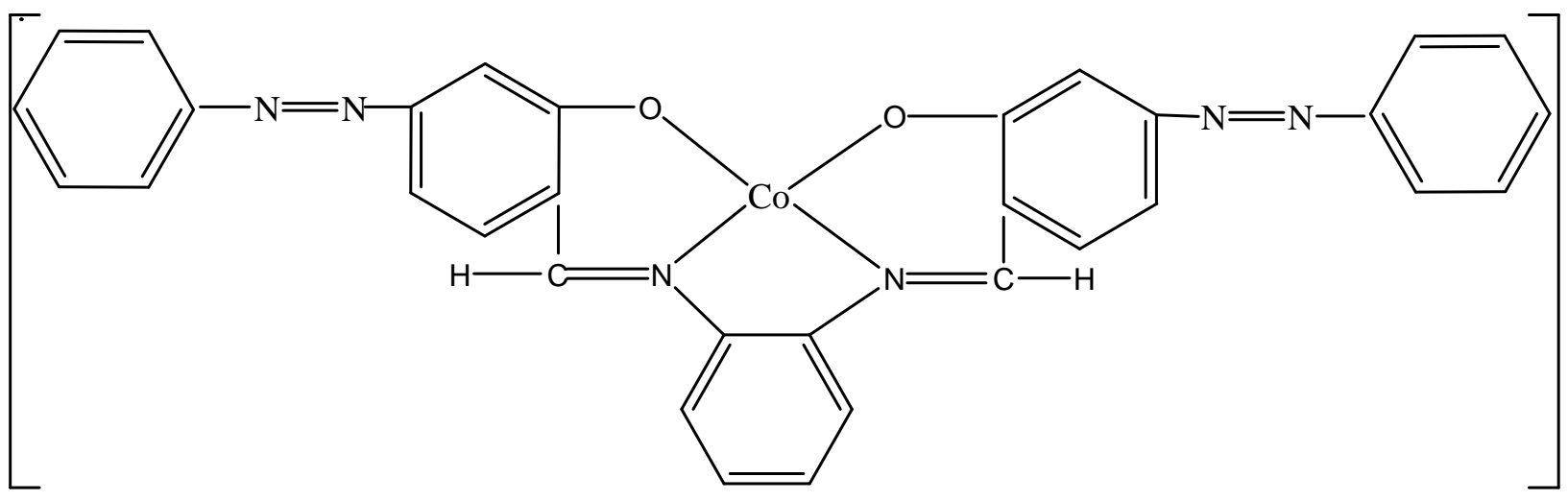

Figure 1: Proposed molecular structure of the cobalt(II) Schiff base complex.

Table 1: Physical properties of the Schiff base ligand and its cobalt(II) complex

\begin{tabular}{llccc}
\hline Compound & Colour & Melting point $\left({ }^{\circ} \mathbf{C}\right)$ & Decomp. temp $\left({ }^{\circ} \mathbf{C}\right)$ & Percentage $(\%)$ \\
\hline Schiff base & Orange yellow & 193 & - & 70 \\
{$[\mathrm{CoL}]$} & Brown & - & 257 & 65 \\
\hline
\end{tabular}

Table 2: Solubility of the Schiff base and its cobalt(II) complex

\begin{tabular}{lccccccc}
\hline Compound & $\mathbf{H}_{\mathbf{2}} \mathbf{O}$ & Ethanol & Benzene & Acetone & Methanol & DMSO & DMF \\
\hline Schiff base & IS & S & SS & SS & S & S & S \\
{$[\mathrm{CoL}]$} & IS & SS & IS & IS & SS & S & S \\
\hline
\end{tabular}

Key: S - Soluble, SS - Slightly Soluble, IS - Insoluble

Table 3: Conductivity measurement of the cobalt(II) Schiff base complex

\begin{tabular}{|c|c|c|c|}
\hline Schiff base complex & Concentration $\left(\mathrm{moldm}^{-3}\right)$ & $\begin{array}{l}\text { Electrical Conductivity } \\
\left(\mathrm{Ohm}^{-1} \mathrm{~cm}^{-1} \times 10^{-6}\right)\end{array}$ & $\begin{array}{c}\text { Molar Conductivity } \\
\left(\mathrm{Ohm}^{-1} \mathrm{~cm}^{2} \mathrm{~mol}^{-1}\right)\end{array}$ \\
\hline [CoL] & $1 \times 10^{-3}$ & 4.6 & 4.6 \\
\hline
\end{tabular}

Table 4: Infrared spectral data of the Schiff base and its cobalt(II) complex

\begin{tabular}{|c|c|c|c|c|}
\hline Compound & $v(C=N) \mathrm{cm}^{-1}$ & $V\left(\right.$ phenolic C - 0) $\mathrm{cm}^{-1}$ & $V(\mathrm{M}-\mathrm{N}) \mathrm{cm}^{-1}$ & $V(M-0) \mathrm{cm}^{-1}$ \\
\hline Schiff base & 1590 & 1340 & - & - \\
\hline [CoL] & 1530 & 1336 & 585 & 511 \\
\hline
\end{tabular}

Table 5: Antibacterial activity of Schiff base and its cobalt(II) complex

\begin{tabular}{|c|c|c|c|c|c|c|c|c|c|}
\hline Compound & \multicolumn{2}{|c|}{ Clinical isolate } & \multicolumn{7}{|c|}{ Diameter / Concentration } \\
\hline & E. coli spp & Staph spp & $3000 \mu \mathrm{g}$ & 2000 & & 10 & & & \\
\hline Schiff base & $\sqrt{ }$ & $\sqrt{ }$ & $11 \mathrm{~mm} \quad 00$ & 00 & 00 & 00 & 00 & 00 & 00 \\
\hline [CoL] & $\sqrt{ }$ & $\sqrt{ }$ & $25 \mathrm{~mm} 16 \mathrm{~mm}$ & $18 \mathrm{~mm}$ & 00 & 00 & 00 & 00 & 00 \\
\hline
\end{tabular}

Table 6: Antifungal activity of Schiff base and its cobalt(II) complex

\begin{tabular}{|c|c|c|c|c|c|c|c|c|}
\hline \multirow[t]{2}{*}{ Compound } & Clinical isolate & \multicolumn{7}{|c|}{ Diameter /Concentration } \\
\hline & A niger C. albican & $3000 \mu g$ & & Opg & 10 & & & rol \\
\hline Schiff base & $\sqrt{ }-\sqrt{ }$ & $13 \mathrm{~mm} 15 \mathrm{~mm}$ & 00 & $10 \mathrm{~mm}$ & 00 & 00 & 00 & 00 \\
\hline$[\mathrm{CoL}]$ & $\sqrt{ }$ & $15 \mathrm{~mm} 22 \mathrm{~mm}$ & $14 \mathrm{~mm}$ & $19 \mathrm{~mm}$ & 00 & 00 & 00 & 00 \\
\hline
\end{tabular}


Table 7: Dissociation constant(pKa) of the tetradentate Schiff base

\begin{tabular}{|c|c|c|c|c|c|c|c|c|}
\hline S/No & & Vol. of $\mathrm{NaOH}\left(\mathrm{cm}^{3}\right)$ & pH & {$\left[\mathbf{H}^{+}\right]$} & {$\left[\mathrm{OH}^{-}\right]$} & {$\left[\mathrm{Na}^{+}\right]$} & $\mathbf{A}_{\text {total }}$ & pKa \\
\hline 1 & 200.5 & 0.5 & 9.56 & $1.80 \mathrm{E}-10$ & $8.80 \mathrm{E}-05$ & $1.20 \mathrm{E}-03$ & 0.01995 & 10.9645 \\
\hline 2 & 201.0 & 1.0 & 9.91 & $8.20 \mathrm{E}-11$ & $2.00 \mathrm{E}-04$ & 2.39E-03 & 0.0199 & 10.9919 \\
\hline 3 & 201.5 & 1.5 & 10.22 & $4.00 \mathrm{E}-11$ & 4.00E-04 & 3.57E-03 & 0.019851 & 11.1152 \\
\hline 4 & 202.0 & 2.0 & 10.51 & $2.10 \mathrm{E}-11$ & 7.80E-04 & 4.75E-03 & 0.019802 & 11.2851 \\
\hline 5 & 202.5 & 2.5 & 10.74 & $1.20 \mathrm{E}-11$ & $1.33 \mathrm{E}-03$ & 5.93E-03 & 0.019753 & 11.4323 \\
\hline 6 & 203.0 & 3.0 & 10.93 & $7.90 \mathrm{E}-12$ & 2.05E-03 & 7.09E-03 & 0.019704 & 11.5684 \\
\hline 7 & 203.5 & 3.5 & 11.07 & $5.70 \mathrm{E}-12$ & $2.84 \mathrm{E}-03$ & $8.26 \mathrm{E}-03$ & 0.019656 & 11.6639 \\
\hline 8 & 204.0 & 4.0 & 11.18 & $4.40 \mathrm{E}-12$ & $3.65 E-03$ & $9.41 \mathrm{E}-03$ & 0.019608 & 11.7356 \\
\hline 9 & 204.5 & 4.5 & 11.27 & $3.60 \mathrm{E}-12$ & 4.49E-03 & $1.06 \mathrm{E}-02$ & 0.01956 & 11.7916 \\
\hline 10 & 205.0 & 5.0 & 11.34 & $3.10 \mathrm{E}-12$ & $5.28 \mathrm{E}-03$ & 1.17E-02 & 0.019512 & 11.8233 \\
\hline 11 & 205.5 & 5.5 & 11.41 & 2.60E-12 & $6.20 \mathrm{E}-03$ & $1.28 \mathrm{E}-02$ & 0.019465 & 11.8702 \\
\hline 12 & 206.0 & 6.0 & 11.46 & $2.30 \mathrm{E}-12$ & 6.96E-03 & $1.40 \mathrm{E}-02$ & 0.019417 & 11.8816 \\
\hline 13 & 206.5 & 6.5 & 11.51 & $2.10 \mathrm{E}-12$ & 7.81E-03 & $1.51 \mathrm{E}-02$ & 0.01937 & 11.9031 \\
\hline 14 & 207.0 & 7.0 & 11.55 & $1.90 \mathrm{E}-12$ & 8.56E-03 & $1.62 \mathrm{E}-02$ & 0.019324 & 11.9064 \\
\hline 15 & 207.5 & 7.5 & 11.58 & $1.80 \mathrm{E}-12$ & $9.18 \mathrm{E}-03$ & 1.73E-02 & 0.019277 & 11.8877 \\
\hline 16 & 208.0 & 8.0 & 11.63 & $1.60 \mathrm{E}-12$ & $1.03 \mathrm{E}-02$ & 1.85E-02 & 0.019231 & 11.9365 \\
\hline 17 & 208.5 & 8.5 & 11.66 & $1.50 \mathrm{E}-12$ & $1.10 \mathrm{E}-02$ & $1.96 \mathrm{E}-02$ & 0.019185 & 11.9306 \\
\hline 18 & 209.0 & 9.0 & 11.69 & $1.40 \mathrm{E}-12$ & $1.18 \mathrm{E}-02$ & 2.07E-02 & 0.019139 & 11.9301 \\
\hline 19 & 209.5 & 9.5 & 11.72 & $1.30 \mathrm{E}-12$ & 1.27E-02 & $2.18 \mathrm{E}-02$ & 0.019093 & 11.9353 \\
\hline 20 & 210.0 & 10.0 & 11.74 & $1.20 \mathrm{E}-12$ & $1.33 \mathrm{E}-02$ & 2.29E-02 & 0.019048 & 11.9082 \\
\hline
\end{tabular}

Average pKa $=11.67308$

Table 8: Determination of average number of coordinated Schiff base to cobalt(II) ion

\begin{tabular}{|c|c|c|c|c|c|c|c|}
\hline S/NO & $\operatorname{Vol}\left(\mathrm{cm}^{3}\right)$ & pH & {$\left[\mathrm{H}^{+}\right]$} & {$\left[\mathrm{OH}^{-}\right]$} & $M_{\text {total }}$ & $\log \left[A^{2-}\right]$ & $\overline{\mathbf{n}}$ \\
\hline 1. & 0.00 & 2.3 & 0.0033535 & $4.81615 \mathrm{E}-12$ & & & \\
\hline 2. & 0.20 & 2.33 & 0.0031297 & $5.1606 \mathrm{E}-12$ & 5.00E-03 & -11.84 & 0.51 \\
\hline 3. & 0.40 & 2.39 & 0.0027258 & 5.92516E-12 & 4.99E-03 & -11.87 & 0.51 \\
\hline 4. & 0.60 & 2.48 & 0.0022156 & 7.28954E-12 & 4.99E-03 & -11.94 & 0.49 \\
\hline 5. & 0.80 & 2.55 & 0.0018858 & 8.56446E-12 & 4.98E-03 & -11.99 & 0.49 \\
\hline 6. & 1.00 & 2.65 & 0.001498 & 1.0782E-11 & 4.98E-03 & -12.15 & 0.51 \\
\hline 7. & 1.20 & 2.76 & 0.0011628 & 1.38899E-11 & 4.97E-03 & -12.53 & 0.52 \\
\hline 8. & 1.40 & 2.94 & 0.0007682 & 2.10233E-11 & 4.97E-03 & -12.19 & 0.52 \\
\hline 9. & 1.60 & 3.18 & 0.0004421 & 3.65342E-11 & 4.96E-03 & -11.57 & 0.53 \\
\hline 10. & 1.80 & 3.77 & 0.0001136 & $1.42135 \mathrm{E}-10$ & 4.96E-03 & -10.78 & 0.55 \\
\hline 11. & 2.00 & 4.52 & $2.021 \mathrm{E}-05$ & 7.99282E-10 & 4.95E-03 & -9.99 & 0.61 \\
\hline 12. & 2.20 & 5.31 & 3.277E-06 & 4.92833E-09 & 4.95E-03 & -9.19 & 0.68 \\
\hline 13. & 2.40 & 6.81 & $1.036 \mathrm{E}-06$ & $1.55848 \mathrm{E}-08$ & 4.94E.03 & -8.69 & 0.76 \\
\hline 14. & 2.60 & 6.18 & 4.421E-07 & 3.65342E-08 & 4.94E.03 & -8.32 & 0.84 \\
\hline 15. & 2.80 & 6.54 & $1.93 \mathrm{E}-07$ & 8.36951E-08 & 4.93E-03 & -7.96 & 0.92 \\
\hline 16. & 3.00 & 7.01 & $6.539 \mathrm{E}-08$ & 2.47002E-07 & 4.93E-03 & -7.49 & 0.99 \\
\hline 17. & 3.20 & 7.58 & $1.76 \mathrm{E}-08$ & $9.17698 \mathrm{E}-07$ & 4.92E-03 & -6.92 & 1.08 \\
\hline 18. & 3.40 & 7.93 & 7.861E-09 & 2.05447E-06 & 4.92E-03 & -6.57 & 1.16 \\
\hline 19. & 3.60 & 8.05 & 5.963E-09 & 2.70832E-06 & 4.91E-03 & -6.45 & 1.24 \\
\hline 20. & 3.80 & 8.1 & 5.315E-09 & $3.03879 E-06$ & 4.91E-03 & -6.39 & 1.32 \\
\hline 21. & 4.00 & 8 & 6.691E-09 & 2.41379E-06 & 4.90E-03 & -6.49 & 1.39 \\
\hline 22. & 4.20 & 8.04 & $6.102 \mathrm{E}-09$ & 2.64667E-06 & 4.90E-03 & -6.46 & 1.48 \\
\hline 23. & 4.40 & 7.89 & 8.62E-09 & 1.8737E-06 & 4.89E-03 & -6.61 & 1.56 \\
\hline 24. & 4.60 & 7.95 & 7.508E-09 & 2.1513E-06 & 4.89E-03 & -6.55 & 1.64 \\
\hline 25. & 4.80 & 8 & 6.691E-09 & 2.41379E-06 & 4.88E-03 & -6.49 & 1.72 \\
\hline 26. & 5.00 & 8.07 & 5.695E-09 & 2.83596E-06 & 4.88E-03 & -6.43 & 1.79 \\
\hline 27. & 5.20 & 7.99 & 6.847E-09 & $2.35885 E-06$ & 4.87E-03 & -6.51 & 1.88 \\
\hline 28. & 5.40 & 7.92 & 8.045E-09 & 2.00771E-06 & 4.87E-03 & -6.58 & 1.96 \\
\hline 29. & 5.60 & 8.01 & 6.539E-09 & $2.47002 E-06$ & 4.86E-03 & -6.49 & 2.04 \\
\hline 30. & 5.80 & 8.06 & 5.828E-09 & $2.77141 \mathrm{E}-06$ & $4.86 \mathrm{E}-03$ & -6.44 & 2.12 \\
\hline
\end{tabular}

Average $\mathrm{n}$ value $=1.130$ 
Table 9: Stability constant and the Gibb's free energy of the complex Compound Stability constant(K)

$[\mathrm{MnL}]$

$3.16 \times 10^{11}$

Gibb's Free Energy

$\left(\mathrm{kJmol}^{-1}\right)$

\section{REFERENCES}

Abdulsamath S., Raman M., Raman N.(1992). Complexes of copper(II) cinnamaldene. Transition metal chemistry, 17(13): 105 129

Ahmed, A. and Akhtar, F.(1983): $\mathrm{Cu}(\mathrm{II})$ and $\mathrm{Ni}(\mathrm{II})$ complexes with a tetradentate Schiff base derived from 2-hydroxy-1naphthaldehyde and ethylenediamine, Indian Journal Chemistry. 20A; 737-758

Angelici, R.J.(1977). Synthesis and Technique in inorganic chemistry $2^{\text {nd }}$ Edition, W.B. Saunder Company Philadelphia, London,Toronto pp115-125

Chohan Z.H, Arif M. mohammed A and Claudiu T.S(2006). Synthesis, characterization and invitro Biological Evaluation of $\mathrm{Co}(\mathrm{II}), \mathrm{Cu}(\mathrm{II})$, $\mathrm{Ni}(\mathrm{II})$ complexes with Amino acid-derived compounds. Bio-inorganic chemistry and applicatgions Article ID 83131, Pp 1-13.

Gavali L. V. and Henkarep P. P.(2007). Synthesis and characterization of the complexes of some transition metals with 4-[2-hydroxy salicylidene-5'(2"-thiozolyazo)] chlorobenzene. Journal of physical sciences, 11: $147-155$.

Geary W.J.(1971): The use of conductivity measurements in Organic Solvents for
Characterization of Coordination Compounds, Coord. Chem. Review, 7(1), $81-122$.

Gregory S., Thomas B.R. and Robert, J.A(1978). Synthesis and techniques in inorganic chemistry $3^{\text {rd }}$ edition, Longman publishers, London. . 119-126

Holm R. H., Everett G. W., and Chakravorty A.(1966), Metal complexes of Schiff bases and $\beta-$ ketoimines, Progr. Inorg. Chem., 7: $83-214$.

Jianning, L. Bo-wan W. Bing Z and Yungchun I(2005) "Synthesis and characterization of Metal complexes of $\mathrm{Cu}(\mathrm{II}), \mathrm{Ni}(\mathrm{II}), 2 \mathrm{n}(\mathrm{II}), \mathrm{Co}(\mathrm{II})$, $\mathrm{Mn}$ (II) and Cadimium. Turk J hem vol.30 pp.11- 18 published by Tubikak.

Mishra P., Gupa P. N. and Shakya A. K.(1991). Synthesis of Schiff base of 3-amino-2methylquinazoline-4(3H)-ones and their antimicrobial activities. Journal Indian Chemical Society. 68: $539-541$.

Saxena C. G. and Shivastava. S. V.(1987). Mn(II), $\mathrm{Co}(\mathrm{II}), \mathrm{Ni}(\mathrm{II})$ and $\mathrm{Cu}(\mathrm{II})$ complexes with $\mathrm{p}$ toly-2-furylgoxalimine. Journal Indian Chemical Society. 64: $685-686$.

Singh K, Barwa M.S and Tyagi P(2006). Synthesis, characterization of biological studies of $\mathrm{Co}(\mathrm{II}), \mathrm{Ni}(\mathrm{II}), \mathrm{Cu}(\mathrm{II})$ and $\mathrm{Zn}(\mathrm{II})$ complexes with bidentated Schiff bases derived by heterocyclic Ketones: Eur.J. Med Chem., 41 Pp147-153. 